\title{
Burning Woman: Sexualized Robots and the Vilification of Women in Metropolis and its Precursors Cassian Grove*, Comparative Literature
}

\begin{abstract}
The vilification and subsequent destruction of feminine robots is a surprisingly common trope in film and literature. This essay draws connections between three very different works-Fritz Lang's Metropolis, Villier's Tomorrow's Eve, and E.T.A. Hoffman's The Sandman-and posits a shared narrative reason for the deaths of the three artificial women: male projection. Comparing and contrasting the three death scenes with each other as well as other texts on feminine literature and projection demonstrates how little substance there is to these "out of control" women/technologies beyond the faults of the men who create them. Furthermore, this essay brings up a prudent question: could these artificial women have become something more if it were not for the displaced guilt and projected egos of the men around them?
\end{abstract}

If you're a beautiful, feminine robot in E.T.A. Hoffman's The Sandman (1816), Auguste Villiers de l'Isle-Adam's Tomorrow's Eve (1886), or Fritz Lang's Metropolis (1927), don't expect to live through the end of the story. All three works feature artificial women ranging in capacity from simple automata to hyper-advanced AI; all three are at some point loved by a heroic man, and all three meet similarly destructive ends. Remarkably, no one appears to have written a direct comparison of these three works, even though they express an idea that is as relevant today as it was in the times these books were created: the projection-screen woman and the helpless man who is driven to madness by her alluring presence. One could argue that since these robotic women all deceive their leading gentlemen, they "get what's coming to them," narratively speaking. However, I propose that each of these feminine robots is, to some degree, largely a projection of a man's ego. Their sins are really the sins of the men who create or love them, and by destroying these specifically feminine images of sin, the men purge themselves of their own failings.

Melissa Bailar's "Uncanny Anatomies/Figures of Wax" provides an excellent summary of Metropolis and Tomorrow's Eve, which I believe can be extended to The Sandman as well: "For the inventors, it is a matter of projecting technological authority; for the androids, subservience and sexual availability" (Bailar 245). We see this in real life when men blame women for their own sexual fantasies and immoral desire-it is argued that the way a woman is dressed, her 
"promiscuous" behavior, the way her body looks, are all things that could tempt a man and make him act immorally. This hypothetical man takes his own desires and actions, which he knows are considered wrong, and places-or projects - them onto a woman so he can absolve himself of guilt and blame. In fiction where the female figure is a robot, she becomes the scapegoat for everything her real-life counterpart has "driven" a man to do, and the narratives of these three stories in particular try to convince us that they-artificial women in the literal sense as well as those in the figurative sense-are indeed wicked temptresses and false idols.

The commonalities that these works share are clear. All three texts feature a memorable moment when the robotic character is first created, revealed, or projected onto: the scene in The Sandman where the clockwork Olympia awakens and seems to fill with life when the protagonist looks at her through a spyglass, the scene in Tomorrow's Eve when the robot Hadaly emerges from behind a curtain, and the iconic scene from Metropolis where we see the heroine Maria's face literally projected onto that of an emotionless automaton. All three robots are created by pairs of men-no women are actively involved. All three are also examples of the phenomenon known as projection: Olympia is a projection of the leading man's ego; Hadaly is a projection of Alicia, a flawed but beautiful human woman; Maria is a projection of Hel, the now-deceased woman beloved by both of this robot's creators. Finally, all three robots are utterly destroyed in scenes involving fire. These commonalities are no coincidence, for the works all exist within an early Western canon of science fiction, and each takes its influence from the last. In "The Eroticism of Artificial Flesh in Villiers de L'Isle Adam's L'Eve Future," author Patricia Pulham credits The Sandman for the inspiration behind the robotic character in Tomorrow's Eve: "Villiers's novel is clearly indebted to Hoffmann's tale, a debt that is tacitly acknowledged early in the text by an epigraph from The Sandman' that opens the second chapter in Book I ('Tis he! ... Ah! Said I, opening my eyes wide in the dark, it is the Sand-Man!' [TE 8])" (Pulham 1). The similar themes and characters tell us that Metropolis fits within this same canon. There are studies that compare The Sandman and Tomorrow's Eve or Tomorrow's Eve and Metropolis, and these often focus on questions of technology or desire, but considering how closely knit these works are, it is astonishing how little writing there is that connects all three.

Of the three, the clearest example of projection is Olympia, an automaton who functions as an absolute blank slate. Olympia is less a character and more of a prop in Hoffman's The Sandman. In this story, a student named Nathaniel is haunted throughout his life by the sinister nurserytale figure of the Sandman, who takes the form of his late father's associate, Coppelius. Nathaniel has a girlfriend, Clara, who politely listens to his stories about Coppelius even though she clearly finds them boring. Through a looking-glass given to him by Coppelius' doppelgänger, Nathaniel espies the beautiful Olympia, supposed daughter of his professor, Spalanzani. He falls madly in love with her, instantly forgetting Clara and anything else about his life. It helps that Olympia is the perfect listener-all she can say is "ah! Ah!" while her admirer, Nathaniel, takes this utterance however best it suits his ego. His projection is quite explicit:

It seemed to him that what Olympia said of his work, of his poetic talent in general, came from the depths of his own being, that her voice was indeed the voice of those very 
depths themselves. And that must actually have been the case, for Olympia never said anything more than the words already mentioned. (Hoffman 118)

The reason why her utterances on his work seem to come from the "depths of his own being" is because they are simply his own thoughts. This is something that would make many contemporary readers chuckle, as almost everyone knows a man who would love nothing more than a conversational partner like Olympia. She embodies the idea that women only exist to reflect men's own ideas and identities. Additionally, in The Uncanny, Freud would argue that Nathaniel also projects his own issues with his father onto Olympia: "this automatic doll can be nothing else but a materialization of Nathaniel's feminine attitude towards his father in his infancy... Olympia is, as it were, a dissociated complex of Nathaniel's which confronts him as a person, and Nathaniel's enslavement to this complex is expressed in his senseless obsessive love for Olympia" (Freud 232 n.1). Perhaps the reason why Nathaniel is so easily fooled by a notedly simple clockwork woman is that this complex has blinded him to the truth. In essence, it's hardly about Olympia and all about Nathaniel.

When Nathaniel walks in on Coppelius and Spalanzani fighting over her, she is ripped apart, and Nathaniel comes to a realization of her true nature, entirely destroying his beautiful projection screen:

At this point Nathaniel saw that a pair of blood-flecked eyes were lying on the floor and staring up at him; Spalanzani seized them with his uninjured hand and threw them at him, so that they struck him in the chest. Then madness gripped him with hot glowing claws, tore its way into him and blasted his mind. (Hoffman 120)

This gruesome end reveals how thoroughly he has been deceived and how literally fragile his sense of self is, so he snaps. His vision of a perfect woman who can only receive his ideas and never contribute her own is revealed to be nothing more than a simple clockwork mechanism. Because he projected so much onto her, seeing her disassembled like this unsettles his mind. It is worthwhile to note that, while Olympia's demise is not related to fire, there are a lot of fiery words used in the scene, such as Nathaniel's madness gripping him with "hot glowing claws" and "flaring into a furious rage" (Hoffman 119). Olympia neither rebels nor intentionally manipulates anyone, but somehow she deceives Nathaniel far more than the leading men of the other two stories are ever deceived. In fact, it is this inaction that captures his heart, as it makes her the perfect blank slate for him to project onto. When she is revealed to be nothing more than a simple automaton and falls apart in the hands of her creators, so does his mental state: "The words he had been shouting dissolved into an awful animal bellowing. Thus, raging in hideous frenzy, he was taken to the madhouse" (Hoffman 120). It seems that these unnatural women awaken something too natural ("animal") in men, and this frenzy of madness is assumed to be beyond a man's control. Rather than putting the onus on the men to regain control, the narratives show that women (robotic ones in The Sandman and Metropolis or heartless human women in Tomorrow's Eve) are the undeniable causes of this chaos and must be destroyed for it to end. It is always the feminine figure who is the homewrecker, the temptress, the instigator, never the man who actually acts. 
In utter contrast, Hadaly from Tomorrow's Eve is articulate and intelligent, though arguably sentient: "She is the skeleton of a shade waiting for the SHADE to exist!" (Villiers 61). Tomorrow's Eve is a work of speculative fiction starring Thomas Edison, in which the acclaimed inventor assists his friend, Lord Ewald, who has fallen in love with a beautiful but emotionally shallow woman named Alicia. Alicia is compared with another beautiful temptress, Evelyn, who is blamed for driving an honest man, Edison's friend Edward Anderson, to adultery. Anderson's life ends up in ruins, and Evelyn, who Edison calls a "deadly female" (Villiers 108), leaves him. It turns out that Evelyn's beauty is entirely artificial-a wig, makeup, tights, etc. Edison reveals that he has invented a mechanical woman (whom he has dubbed Hadaly) that can surpass humanity in her perfection and proposes that he transpose the image of Alicia onto this automaton. Edison claims that, even though this automaton will have a limited number of pre-recorded things she can say, she will still surpass any human woman as a conversational partner because Ewald can memorize the timing of her phrases and construct conversations around her as appropriate. In short, she will be the perfect partner because the things she says will only ever mean what Ewald wants them to. Hadaly is not without her rebellion, however, and has secrets even from her genius creator. Anderson's ex-wife, whom Edison has hypnotized and renamed Sowana, has secretly stowed her consciousness away in Hadaly's body.

We also see from Edison's story of his adulterer friend and his reaction to Ewald's story that he blames beautiful women for seducing men into adultery or trapping them in loveless relationships: "Such are these women, modern Furies of a sort, for whom the man they select is simply a victim to be weakened and degraded. By kind of fatality, they obey blindly the obscure urgings of their malignant essence" (Villiers 111). He paints both Anderson and Ewald as perfect, noble men, whose only flaw was falling for beauty, which Edison argues is an artifice. These women and their deceit are likened to androids. He proves his point literally with Hadaly, who is just as beautiful and artificial as Alicia:

Well then, I thought, if the artificial, when assimilated to or even amalgamated with human nature, can produce such catastrophes; and since, consequently, any woman of the destructive sort is more less an Android, either morally or physically--in that case, one artifice for another, why not have the Android herself? (Villiers 123)

While Edison claims that his automaton will seem to be even more real than Alicia, he makes clear that the other difference between Alicia and Hadaly that makes the artificial woman so much better is that she has no will but to be utterly devoted to Ewald. Edison especially is a fantastic example of Bailar's "projection of authority" and Hadaly a fantastic example of the subservient and sexually available android-at least until she begins to act on her own and become the threatening "out of control" female.

The book praises Edison with such high esteem that it is hard to know how much the narrative holds his opinion as correct and how much it satirizes him, but his voice is unchallenged by all but Hadaly's small rebellion. Therefore, through Edison, we see a Madonna/whore complex arise in this story. Hadaly, for example, is often compared to Eve, and Alicia (who we see is simply a bit self-involved) is painted as a deceitful, empty creature. The phenomenon we now know as slut- 
shaming has been around for a long time and often involves the comparison of unfavorable women (who are promiscuous and somehow both scheming and unintelligent) and favorable ones (who are chaste for all except their husbands). Since the narrative is so very colored with the opinions of Ewald and Edison, it makes the reader wonder if Alicia really is as bad as they claim. This Madonna/whore dichotomy is one imposed by the patriarchy, and in Tomorrow's Eve especially it's used to blame the "whore" for the negative actions of a man. The man, both modernday and Edison-contemporary, cannot accept his own ignoble feelings, so he invents a slanderous character to project onto a woman in order to absolve himself.

Hadaly is burned to death-destroyed as completely as Olympia, and not for any apparent crime or reason; she is annihilated in a fire that "began in a cargo compartment where several barrels of turpentine and gasoline were ignited by an unknown cause, and soon exploded" (Villiers, 218). The phrase "unknown cause" implies her death was a tragic accident, so if Hadaly is being punished, it is being enacted by the narrative rather than a force within the story. A probable cause comes to light when we examine the psychology of the narrative and consider the biases and misogyny of the time and the author. Of Hadaly's death, Bailar notes: "Once she exerts her mesmerizing pull on Ewald, Hadaly"s body with Sowana's soul becomes Freud's 'harbinger of death,'... similarly causing a fire that directly or indirectly kills Miss Alicia, Ewald, and Anny Anderson." (Bailar, 37). Perhaps it was for exerting this "mesmerizing pull" and becoming too much like a sinful, flesh-and-blood woman that she was punished by the text. Perhaps it's because she dared to have a will of her own and rebelled against her masculine creator.

Even though they spent so little time together, Ewald mourns Hadaly/Sowana more than he does his organic ex-lover: "My friend, only the loss of Hadaly leaves me inconsolable-I grieve only for that shade. Farewell" (Villiers 219). While we can infer that Hadaly has started to take on some personality and autonomy of her own (due to Sowana's influence) through the secret conversation she keeps with Ewald, he mourns a "shade." He mourns a beautiful thing that he could project himself onto, not the budding intelligence, and he mourns it fiercely. All the projection-screen-women inspire remarkably strong feelings in their admirers, usually to the point of madness: "During these scenes of horror, a strange incident occurred below decks. Lord [Ewald] seized a capstan bar and tried by main force to rush into the flames where the chests and boxes were already burning fiercely" (Villiers 218). The death of his lover Alicia, meanwhile, is hardly on his mind.

In "Uncanny Anatomies/Figures of Wax," Bailar comments on this madness ignited (or fanned) by Hadaly:

Marie Lathers has similarly suggested that all women exhibit forms of hysteria, which Edison attempts to cure by hypnotising them each in turn. However, the combination of Sowana's occult power, Alicia's beauty, and Hadaly's strong physicality surpasses male domination. It is this hybrid creature that mesmerises Ewald and Edison and in the end reframes both of them as pathological, the one hysterical in his lovelorn yearning, the other in his scientific Madness. (Bailar 36) 
In using the word "reframes," Bailar implies that this pathology was already extant in the two men. While Ewald and Edison would be quick to accuse women of driving men to madness, adultery, and suicide, it is much more likely that all of these ideas exist within them already, and a beautiful woman simply a screen on which to project them. Hadaly is made the scapegoat for these men's madness, but she also reveals that the madness was always there.

As we go through these texts, a common thread emerges: the threat of technology becomes tied to the threat of women. In his essay, "The Vamp and the Machine," Andreas Huyssen discusses this idea:

We can conclude that as soon as the machine came to be perceived as a demonic inexplicable threat and as harbinger of chaos and destruction-a view which typically characterizes many nine-teenth century reactions to the railroad to give but one major exam-ple-writers began to imagine the Maschinenmensch as woman. (Huyssen 203)

We see a prime example of this in Metropolis, which features the iconic robotic Maria. This silent film is set in a hierarchical utopian future, where a man named Joh Frederson rules the eponymous city like a businessman. The working class endures backbreaking labor in the bowels of the city while the wealthy frolic in extravagant luxury above. Joh Frederson's son, Freder, meets Maria, a kind woman who consoles the workers and teaches them about unity. Freder learns about the dark, oppressive side of his father's work, while Frederson meets with a scientist named Rotwang. Rotwang has been building a first-of-its-kind automaton in the image of Frederson's late wife, Hel, with whom Rotwang was also in love. Frederson learns of the influence that Maria has over the workers, so he has Rotwang give the automaton Maria's face instead.

The scene in the laboratory where this transformation occurs is a noteworthy moment for the history of cinema and special effects, as the original Maria lies asleep like Snow White under a half-cylinder of glass while glowing rings of light scan her features. The robot, entirely expressionless, is also encircled by these rings of light, and is slowly altered until it takes on the exact form of Maria. All the connotations of Maria-her beauty, her relationships, her status as a pure and delicate creature-are superimposed onto the robot, albeit transformed: the robotic Maria has a twitching eye. This robot begins life as a cold, intimidating automaton who, in the guise of Maria, becomes sultry, chaotic, and out of control. She performs her assigned task of ruining Maria's reputation among the workers, but she actually ends up driving them to violently rise up against Frederson. While his end goal in using her is unclear, it is unlikely that he wanted this strike to occur, so we can infer that this is the beginning of robotic Maria's break from her programming. After riling up the workers, she dances, scantily dressed, in the midst of high society. The men who witness her are driven mad with lust and end up physically fighting for her. There is a lot of doubt as to whether she is entirely in control, and the camera hints to us that she is acting beyond the parameters of her programming. There is a strong focus on her eyes: the actress has an unnerving talent of keeping one eye half-lidded when she plays the robotic Maria, and the heavy eyeliner adds to the effect. This focus creates a sense of threat, it lets the audience know that she is unhinged, and that she is a menace who seduces men into violent and thoughtless deeds-but of course, she is the one blamed for these deeds by the narrative. The out-of-control 
woman is a timeless idea; one only has to harken back to the media treatment of Britney Spears during her famous breakdown (or any other female child star) to see how our society reviles and shuns a woman who behaves erratically. It's possible that this effect is in part the fault of stories that equate an out-of-control woman to an out-of-control machine, which was an even scarier thought when Metropolis was made than it is now. What's threatening about the "false" Maria isn't that she's a robot, but rather that she's a robotic woman who acts out and dances provocatively, making the men around her lose their wits.

In his essay “The Vamp and the Machine," Huyssen insists that the threat of technology is tied to the threat of femininity:

What is most interesting about Metropolis is the fact that in both forms, femininity, imagined as it is from the male perspective, poses a threat to the male world of high technology, efficiency, and instrumental rationality. (Huyssen 206)

While the camera focuses on her dark smirk and sensual eyes, there is nothing so fantastical about this Maria that she alone could influence a person's mind to act violently. No matter what the intention behind her programming is, there is no textual evidence for any powers that could actually drive men to violence, so why is it not the men who are blamed for behaving violently? The narrative camera would have us believe that Maria is manipulating them, that she is the purposeful cause of this physical outburst, but no matter what her intentions are, all she does is dance-and very robotically, at that. What the filmmaker might not want his audience to consider is that these desires and lusts are already within these men and that they are incapable of reigning in their own behavior and emotions. Maria, in her minimal outfit and strange movements, proves to be an effective scapegoat for their feelings and actions.

In addition to this, Freder projects his pseudo-Oedipal fears onto her when, believing she is the real Maria, he sees her embracing his father. Freder then falls into a bout of prolonged and feverish madness as a result of seeing the woman he loves in the arms of his father. It is in fact a rather chaste embrace that could easily be read as paternal, but Maria's ever-sultry eyes would have Freder and the audience believe it is something more. In fact, the wild femininity is an invention of these men. We, the audience, are meant to fear this Maria. Yes, she is a robot gone haywire, which is a theme that can often be terrifying, but she never actually hurts anyone. All the pain and suffering in the movie is caused or imagined by the male characters.

Michael Tritt's chapter "Young Goodman Brown' and the Psychology Of Projection from Studies in Short Fiction" has an apt description of this particular phenomenon of projection:

Yet the process of projection classically functions to defend the individual from his anxiety. The result is that while guilt persists, it persists only at the subconscious level. Brown's desperation at the end of the story is not primarily, then, the result of a guiltconsciousness but rather originates with the guilt he is unable to recognise and admit. Conceiving of himself as unscathed, Brown obsessively locates the source of his anxieties of those around him. (Tritt 114) 
All three men in these scenes take the sins to which they are unable to admit and project them onto Maria. Frederson's corruption and lust for power, Rotwang's desire for Frederson's dead wife and to destroy Frederson, and Freder's own complicated feelings about his father, his connection to power, and Maria-all these are displaced onto the robotic Maria. She is only an automaton, albeit a remarkably advanced one, but she becomes the leading villain of the story until her death. When the movie was made, the audience was supposed to root for this; the film shows her cackling gleefully throughout her death scene like so many burned witches, so clearly we are to imagine her as wicked. Today, however, the scene can inspire a sense of unease. How many people have been vilified because they belong to a group without the institutional power to defend themselves? How many have been blamed for the crimes committed against them?

With the seductress who represents all their insecurities and failings dead, Freder is free from her spell, Rotwang falls to his death, and Joh realizes his wrongdoings and repents. Her death is noteworthy, for it raises questions as to why a supposedly unfeeling robotic creation would have such manic glee over her own destruction. Is this simply the influence of her mad genius creator, Rotwang? Or is there something more to her beyond the wills, fears, and projections of the men around her? As interesting as that would be to explore, this is likely not the case. When robotic Maria's beautiful skin melts away during the witch-burning scene, we see again the cold, stiff, unfeeling android that she had been underneath throughout the entire movie. This implies something surprisingly subtle for this film: that unhinged femininity, rather than out-of-control machines, was the true threat all along.

In this way or another, all three women are burned like witches, because fire is the most violent and destructive force at hand. The deception and reveal of Olympia's eyes contrasts with the focus on the robot Maria's eyes, which are her giveaway. Maria's lopsided, half-lidded gaze and heavy eyeliner lets the audience know that this is not the original Maria. In both cases, the eyes betray the artificial woman's soullessness-the artificial Maria's lack of morality and Olympia's artificiality. Between the two, however, the narrative of The Sandman frames Olympia's destruction as a punishment for Nathaniel's projecting onto and idealizing her, whereas the narrative of Metropolis punishes Maria for driving men mad. Both destructions are utterly thorough and nearly over-the-top, as we see Olympia torn limb-from-limb and Maria set ablaze. Today, the consequences for a woman who is labeled a temptress, a homewrecker, a slut, or outof-control are more dire than they would be for the men who committed the alleged crimes.

In the same way that Nathaniel is thrown into madness by this counterfeit woman, the lovers of the other two women are also driven to emotional and psychological extremes. Freder has to be restrained by multiple strong working men in order to keep him from rescuing Maria, and Lord Ewald tries to break into the cargo hold where Hadaly is being kept. The last scene in Tomorrow's Eve notes: "He seemed to be in an absolute frenzy to throw himself into the flames" (Villiers 218). Even though he knows full well that Hadaly is an artificial woman, Ewald is not only willing but desperate to risk his own life to save her. This "frenzy" echoes Nathaniel "flaring into a furious rage" as well as Freder attempting to climb up the burning pyre to rescue Maria. Of course, if it actually were the real Maria up on the pyre, his desire to save her would make sense, but we can plainly see through shots from his perspective that she is cackling as she burns and moving in that 
demonic way he's seen the robot Maria move. Her appearance, therefore, continues to deceive him and drive him into madness. We see this supposed madness today in privileged groups who refuse to learn to control themselves, while oppressed groups must exert extreme control or else be branded as reactionaries and dangers. The real Maria, for example, calls to mind the image of a contemporary woman who must remain unthreatening and reasonable even when fighting an impossible fight for workers' rights, for the credit of the entire movement falls apart if she acts in any way other than sweet and nurturing. We can see this credit dissolve entirely when she is replaced with the robot Maria.

All three artificial women perform their functions exceedingly well, subserviently, and with everlasting "sexual availability," yet they all still must die. What is the crime that suits such punishment? In Metropolis, while the narrative camera often focuses on robotic Maria's wickedlooking expression, all she does is dance in minimal clothing and offer the workers the idea of revolt. The men who are enthralled by her dancing end up fighting over her, and we are to assume this is her fault. The workers take up her ideas without organizing properly or taking measures to protect their children, so this must be her fault as well for inspiring such violent feelings. What she does is take their self-control and power away, so she must be punished. In reality, she does nothing to directly harm anyone. The moral ineptitude is already within the men she affects, but the vision of a beautiful woman is the one blamed for their actions.

In Tomorrow's Eve by contrast, Hadaly saves Ewald from an unfeeling woman who is using him (according to Ewald). As is stated above, the fire that destroys her appears to be a random accident, but there is likely a narrative reason why she could not survive. Perhaps that reason is her and Sowana's little rebellion, the moment where she asks Ewald to keep their conversation secret from Edison. A robot who was simply meant to be a perfectly obedient and loving doll has started to become her own person, and this book does not have the aptitude to explore the consequences and implications of that. If she is a thinking and feeling person, that makes the noble Ewald her warden, keeping and using a sentient being for his own selfish reasons. It could also be because she represents Eve, and by going against her creator, she has fallen. At the top of this chapter, the quote used is from Genesis: "And it repented the Lord that he had made man on the earth, and it grieved him at his heart. And the Lord said, I will destroy man whom I have created" (Genesis 6:6). While Edison has no direct hand in Hadaly's demise, we can see parallels between his creation of Hadaly and God creating mankind. Since Hadaly is becoming something other than what Edison intended, she will be vulnerable to the same sins as humankind. Therefore, she represents the failures of all humans, the man who created her, and the man who loved her, and so she must be destroyed.

So, does the punishment fit the crime? Or is the destruction of these remarkable creations misogynistic overkill? That depends on if these artificial women have anything going on behind the metaphorical projector screen. Bailar certainly thinks so:

The novel indicates that while [Edison] and the narrator may view Alicia as mundane, Anny as a victimised Madonna, and Sowana as obedient, such perspectives gloss over the complexity and agency of these women. These figures join Hadaly in the uncanny and the 
narratively distanced concluding paragraphs come up for they are not as comfortably knowable as the novel depicted them. (Bailar 38)

While this is truer for Tomorrow's Eve than it is for The Sandman or Metropolis, one has to wonder what could have been if the stories had let us into the mind and perspective of these robots, or if a woman had told the story. These automatons are all incredible breakthroughs in the technology and culture of their world, but because they are painted as evil and unnatural, their potential can never be realized. Could Olympia have become something more than a simple automaton? Could the robot Maria have learned to think for herself? What could the combination of Hadaly's might and Sowana's mind accomplish together? What were they beyond the sins of their creators?

Interestingly, the narrative in the end of The Sandman offers something of an answer: the men become so worried about becoming involved in a relationship like his that they actively encourage their partners to behave imperfectly and become bored when listening to their stories, so as to ensure that they are in fact human. As a result of this, "Many love-bonds grew more firmly tied under this regime; others on the contrary gently dissolved" (Hoffman, 122). This is a surprisingly progressive take on relationships, and perhaps shows that in this instance, the artificial woman is not a narrative stand-in for real women, but rather an impossible standard that should not be striven for. It could be argued that Olympia is therefore given the same "homewrecking temptress" treatment as Maria or Alicia, or the same "out of control woman" treatment as Maria and Hadaly, but given how the end of The Sandman is much more willing to acknowledge that its flesh-andblood women characters are flawed people with inner lives, it is possible that there truly is no more to Olympia than what we see.

Each story has a different approach to robotic women, but there are universal truths to all three. Even if we can make inferences about Olympia, the narratives only show us what the male characters project onto these feminine robots, so we can never truly know what, if anything, they could have been beyond that. This omission, however, makes the nature of the robots that much more mysterious. Because the narratives refuse to show the robots outside of a man's perspective, the audience may wonder what they are hiding. These works try to convince us that the threat of women and out-of-control technology warrants a thorough obliteration, but it is clear that these robotic women are simply icons and scapegoats for men-protagonists, antagonists, and authors alike-to exorcise their personal demons. The themes in these works still ring true today. The current environment surrounding misogyny, power imbalances, and rape culture echoes the values these fictional men hold is not the same as it was one or two hundred years ago, but these views of women have remained. Today, at least, this treatment can be deconstructed and challenged. Perhaps it is time to see a story from the perspective of the projection screen and see what truths it uncovers.

\section{ACKNOWLEDGMENTS}

I would like to express my deep appreciation to Katy Brundan for urging me to go further with my paper and supporting me throughout the writing process. 


\section{REFERENCES}

Bailar, Melissa. "Uncanny Anatomies/Figures of Wax.” The Journal of the Midwest Modern Language Association, vol. 49, no. 2, 2016, pp. 29-53. JSTOR, www.jstor.org/stable/44164804. Accessed 20 Mar. 2021.

Freud, S. (2001). The 'Uncanny'. In 13680722071000396612 S. Freud (Author), 1368072209 1000396612 A. Freud, 13680722101000396612 A. Strachey, \& 13680722111000396612 A. Tyson (Eds.), \& 13680722081000396612 J. Strachey (Trans.), The standard edition of the complete psychological works of Sigmund Freud (pp. 219-252). London: Vintage.

Hoffman, E.T.A. The Sandman. In Tales of Hoffman (pp. 85-125). Penguin Classics, 1982.

Lang, F. (Director). (1926). Metropolis [Motion picture]. Germany: Ufa.

Huyssen, A. (1986). The vamp and the machine: Fritz Lang's Metropolis. After the Great Divide, 65-81. doi:10.1007/978-1-349-18995-3_4

Pulham P., (2008) “The Eroticism of Artificial Flesh in Villiers de L'Isle Adam's L'Eve Future”, 19: Interdisciplinary Studies in the Long Nineteenth Century o(7). doi: https://doi.org/10.16995/ntn.486.

Tritt, Michael. "Young Goodman Brown and the Psychology of Projection." Studies in Short Fiction 23.1 (1986): 113. Web.

Villiers de L'Isle-Adam, A., \& Adams, R. M. (2001). Fate. In Tomorrow's Eve (pp. 218-219). Urbana: University of Illinois Press. 